\title{
Best Practices on HVAC Design to Minimize the Risk of COVID-19 Infection within Indoor Environments
}

\author{
Alexandre Fernandes Santos ${ }^{1}$ \\ https://orcid.org/0000-0001-5306-6968 \\ Pedro Dinis Gaspar ${ }^{1,2}$ \\ https://orcid.org/0000-0003-1691-1709
}

\section{Aseel Hamandosh ${ }^{3}$}

https://orcid.org/0000-0002-2658-8039

\author{
Eliandro Barbosa de Aguiar 4 \\ https://orcid.org/0000-0001-9994-7736
}

Antonio Carlos Guerra Filho ${ }^{5}$

https://orcid.org/0000-0003-3631-1348

\author{
Heraldo José Lopes de Souza ${ }^{6}$ \\ https://orcid.org/0000-0002-8471-7804
}

${ }^{1}$ University of Beira Interior, Department of Electromechanical Engineering, Covilhã, Portugal; ${ }^{2} \mathrm{C}-\mathrm{MAST}-\mathrm{Centre}$ for Mechanical and Aerospace Science and Technologies, Covilhã, Portugal; ${ }^{3}$ Catholic University of Paraná; Dentistry; Curitiba, Paraná. Brazil; ${ }^{4}$ Estácio Faculty, Curitiba, Paraná, Brazil; ${ }^{5}$ Federal University of Uberlândia, Minas Gerais, Brazil; ${ }^{\circ}$ Professional Faculty. Curitiba, Paraná, Brazil.

Received: 2020.05.29; Accepted: 2020.06.20.

${ }^{*}$ Correspondence: projetos.etp@gmail.com. (A.F.S.) Tel +55 3332-7025, Curitiba Paraná Brazil.

\section{HIGHLIGHTS}

- Proper air conditioning design is important for air quality.

- HVAC solutions exist to reduce Sars-CoV-2 contamination.

- Best practices on HVAC design to minimize the risk of COVID-19 infection are described.

- Rethinking air conditioning designs with an emphasis on holistic comfort for humans.

Abstract: The spread of Coronavirus is causing in the society all around the world a considerable degree of fear, worry and concern and particularly among healthcare workers that are at increased risk for infection. This paper gathers the strategy/guidelines to reduce the contamination in Intensive care unit (ICU) and in all the hospital environment. The ASHRAE and REHVA guidelines applied the UV-C Lamps, Pressure control filtration, Restroom actions and Humidity control to reduce the coronavirus disease (Covid-19) in ICU. The role of infection control in the design of hospitals is increasing every day. This paper highlights the role of heating, ventilating and air-conditioning minimizing the risk of infection from airborne transmission within the built environment through the application of best practices.

Keywords: Covid 19; pandemic; contamination; strategies; guidelines; best practices. 


\section{INTRODUCTION}

Coronavirus disease (COVID-19) was initially identified in an outbreak of viral pneumonia in Wuhan, Republic of China, in December 2019. The epidemiology of COVID-19 has recently become clearer as incident cases continue to rise and researchers refine estimates of the severity, transmissibility, and populations affected. The spread of Coronavirus is causing in the society all around the world a considerable degree of fear, worry and concern, with around one hundred thousand people being infected worldwide daily $[1,2]$.

Health workers are at the front line of the COVID-19 outbreak response and as such they are exposed to hazards that put them at risk of infection. Hazards include pathogen exposure, long working hours, psychological distress, fatigue, occupational burnout, stigma, and physical and psychological violence [3].

Protecting health care workers and preparedness of Intensive care units (ICUs) to face an epidemic cluster should be the main priority. The role of healthcare workers in the transmission of pathogens from patient-to-patient is well documented, however, increasing evidence reports the contaminated environment as highly significant in pathogen transmission; in particular, high-touch surfaces are recognized as a possible reservoir of infectious agents. Thus, healthcare workers are at increased risk for infection $[4,5,6]$.

Epidemics have the potential to severely strain intensive care resources and may require an increase in intensive care capability. Few intensivists have direct experience of rapidly expanding intensive care services in response to an epidemic. Early preparations should include fit testing of negative pressure respirators, training of reserve staff, sourcing of material for physical modifications to the ICU, among other [7].

Brazil has 50 thousand ICU beds enabled in January, with only 22 thousand of them available through Health Unit System (SUS). The others are from hospitals that provide care only through payment or agreements. According to the Globo journal, a total of 199,768 professionals were identified as suspected cases of the disease and needed to be dismissed [8].

In a state of Brazil (Pernambuco), 1/3 of infected people with coronavirus arehealthcare workers. The Health Secretariat of Pernambuco points out that 377 health professionals tested positive for COVID-19. The number represents one in three cases of the disease registered across the state. The high number is the result of being the first state in the country to test all symptomatic health professionals [9].

The use of face masks has become ubiquitous in the world. The Disposable N95 respirators and medical masks are both worn by for healthcare workers self-protection. However, these masks have different intended uses. N95 respirators are designed to prevent the wearer from inhaling small airborne particles. Thus, they must meet filtration requirements, and fit tightly to the wearer's face, limiting facial seal leakage. Medical masks are intended to prevent microorganism transmission from the wearer to the patient. Medical masks fit the face loosely and do not reliably prevent inhalation of small airborne particles [10].

The coronavirus found in a hospital air duct has led scientists to believe the disease could be spread through air-conditioning units, making it more contagious than initially thought. Evidence of COVID-19 has been found in air conditioning vents in some hospitals, raising the question regarding filtration systems for many buildings $[7,11]$.

Pathogen dissemination through the air occurs through droplets and aerosols typically generated by coughing, sneezing, shouting, breathing, toilet flushing, and some medical procedures. Ventilation systems cannot interrupt the rapid settling of large droplets and they can influence the transmission of droplet nuclei infectious aerosols. Directional airflow can create clean-to-dirty flow patterns and move infectious aerosols to be exhausted $[12,13]$.

This paper gathers the strategy/guidelines to reduce the contamination in Intensive care unit (ICU) and in all the hospital environment.

\section{MATERIALS AND METHODS}

The transmission routes of the infectious agent must be assessed. In relation to COVID-19, the standard assumption is that the following two transmission routes are dominant: via large droplets (droplets/particles emitted when sneezing or coughing or talking) and via surface (fomite) contact (hand-hand, hand-surface etc.). A third transmission route that is gaining more attention from the scientific community is the fecal-oral route [14]. Table 1 includes the relation between aerosol droplets size and exposure time. The droplets can be:

Large droplets (> 10 microns): Airborne transmission through large droplets that are released and fall to surfaces no further than 1-2 meters from the infected person. Droplets are formed from coughing and sneezing. 
Small particles ( $<5$ microns): These may stay airborne for hours and can be transported long distances. They are generated through coughing, sneezing or talking. Small particles (droplet nuclei or residue) form from droplets that evaporate and desiccate. The coronavirus particle is $0.80-0.16$ micrometer and remains active in common indoor air conditions for up to three hours and two to three days on room surfaces. These small particles can stay airborne and travel long distances by airflows in the room or via air ducts of ventilation systems.

Table 1. Aerosol droplets size vs exposure time.

\begin{tabular}{lll}
\hline Aerosol droplets & Exposure Time & First destiny \\
\hline$\leq 5$ microns & around 10800 seconds & Air \\
$\geq 10$ microns & around 6 seconds & Surfaces \\
\hline
\end{tabular}

In hospitals, air conditioning can play a role beyond the promotion of comfort. In many cases, proper air conditioning is a factor in patient therapy. Patients in well-controlled environments generally show more rapid physical improvement than those in poorly controlled environments [15].

The healthcare services should have permanent quality and safety strategies/guidelines. For example, the planning strategies are fundamental to carry out urgent operations during the pandemic, allowing the minimum required people in the surgical room, thus preventing the risk of contamination of other individuals [16].

With the aim of protecting health-care workers, critically ill patients with suspected or confirmed COVID19 infection should ideally be admitted to an airborne infection isolation room that is at negative pressure, as shown in Figure 1. The American Society of Heating, Refrigerating and Air-Conditioning Engineers (ASHRAE) recommended to use Heating, ventilation, and air conditioning (HVAC) systems that can protect healthcare workers and instill confidence by providing safe environment for their interactions with most contagious patients and reduce exposure when patients discharge contaminants during procedure. However, it is recognized that changing the outdoor air amount might impact building pressure balance and also create humidity issues. As stated before, the small size of a coronavirus particle allow it to stay airborne and travel long distances carried by airflows in the rooms or in the extract air ducts of ventilation systems [17].

Figure 1 shows several approaches to change the pressure or filtration system in the ICU room available in the Standard 170 "COVID-19 Guidance" for Hospital Isolation Rooms [18] that advises on HVAC systems, configurations, and modifications to handle a potential surge in COVID-19 patients.

First and second options showed in Figure $1 \mathrm{a}$ ) and Figure $1 \mathrm{~b}$ ) respectively, the duct discharges to the exterior. Option 1 complies with CDC (Centers for Disease Control and Prevention of the United States of America), ASHRAE and FGI (Facility Guidelines Institute). If the room is equipped with High Efficiency Particulate Arrestance (HEPA) units (Option 2), discharging can also be made to the exterior.

Third option shown in Figure $1 \mathrm{cb}$ ) shows in room fan (NON- HEPA) discharging directly to exterior or use existing TLT room exhaust.

Fourth option shown in Figure $1 \mathrm{c}$ ) shows in room HEPA discharging to return. Systems must be balanced to prevent down stream effects.

Fifth option shown in Figure $1 \mathrm{~d}$ ) presents a placed HEPA filtered negative air machine in vestibule, the duct through vestibule to corridor and keep door to vestibule closed but door to patient room open.

Sixth option shown in Figure 1 e) shows a HEPA unit recirculating air in room after scrubbing. Not negative, supply should be covered to prevent high pressure.

All these options consider that returns should be covered (except Option 1) and a distance of 8 meters from final discharge point to opening into building. 


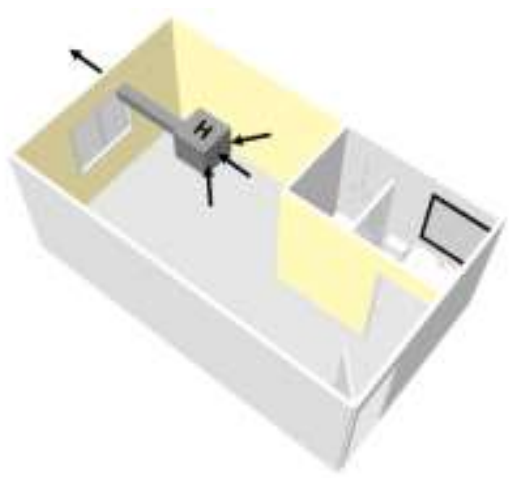

a) Option 1 and Option 2 .

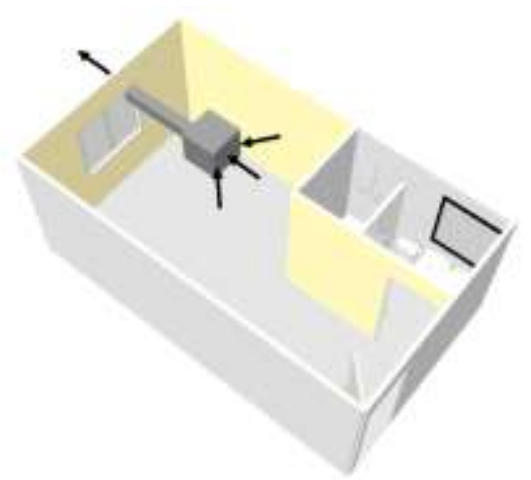

b) Option 3.

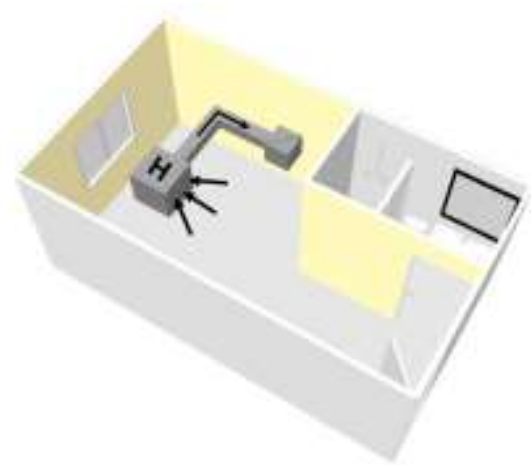

c) Option 4.

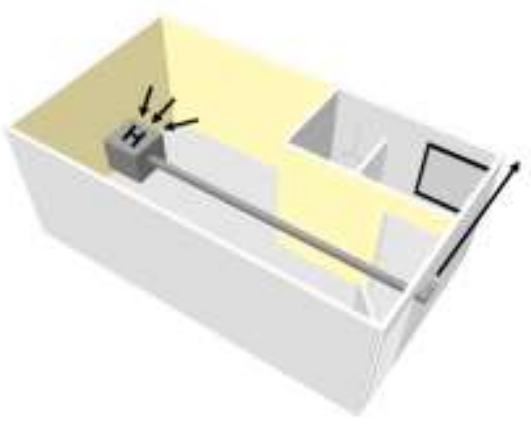

d) Option 5 .

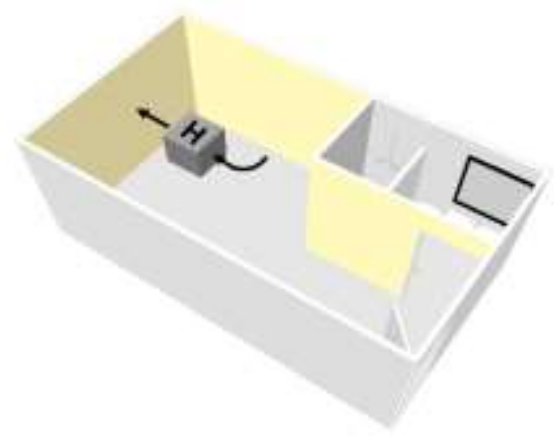

e) Option 6

Figure 1. Approaches to change the pressure or filtration system in the ICU room (adapted from [18]).

Decontamination Unit: Compact decontamination units as shown in Figure 2 can be installed in the room or outside, capturing the air and exhausting it to the outside. Exhaustion must be considered in places with risk of contamination; such as rooms for patients with infectious diseases.

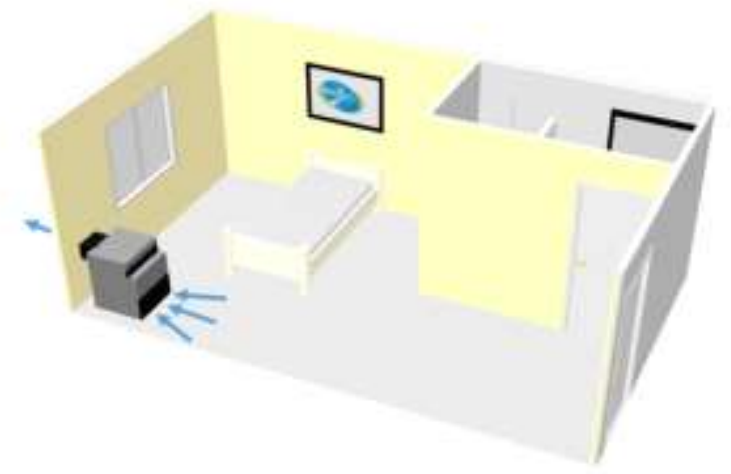

Figure 2. Best simple suggestion, using portable HEPA equipment - Compact decontamination unit.

Research has demonstrated that appropriate air filtration limits the pass-through of virus particles, which frequently hitch a ride on larger particles, into downstream areas. Properly installed higher efficiency filters can remove particles of a relevant size depending on their installed capture efficiency. The National Air Filtration Association (NAFA) described some benefit that can be reasonably inferred for appropriately sized (e.g., their removal rate is appropriate for the room), maintained, and operated portable (HEPA) filters [19]. A study conducted by the National Air Duct Cleaners Association (NADCA) recommended that an HVAC system should be inspected at a minimum, twice a year [20].

Elias and coauthors [21] showed that in hospitals that contain HEPA filtration, localized filtering in hightraffic spaces may further decrease the number of viral particles. A low-cost air purifier containing a HEPA filter can cost aorund $\$ 100$ and renovate the air in a $15 \mathrm{~m}^{2}$ room 5 times per hour and could be deployed widely in hospital environments. It may be worth taking any measures possible to increase airflow speed in existing HVAC systems, and to avoid recirculating air between rooms.

The Federation of European Heating, Ventilation and Air Conditioning Associations (REHVA), has provided interim guidance on the operation and use of building services in areas with a coronavirus disease (COVID-19) outbreak. The guidance aims to prevent the spread of coronavirus through HVAC or plumbing systems [22]. 
According to ASHRAE, REHVA and NAFA, some strategies and guidelines that can applied to reduce the contamination in the ICU and in the hospitals are shown in Figure 3 and described in detail:

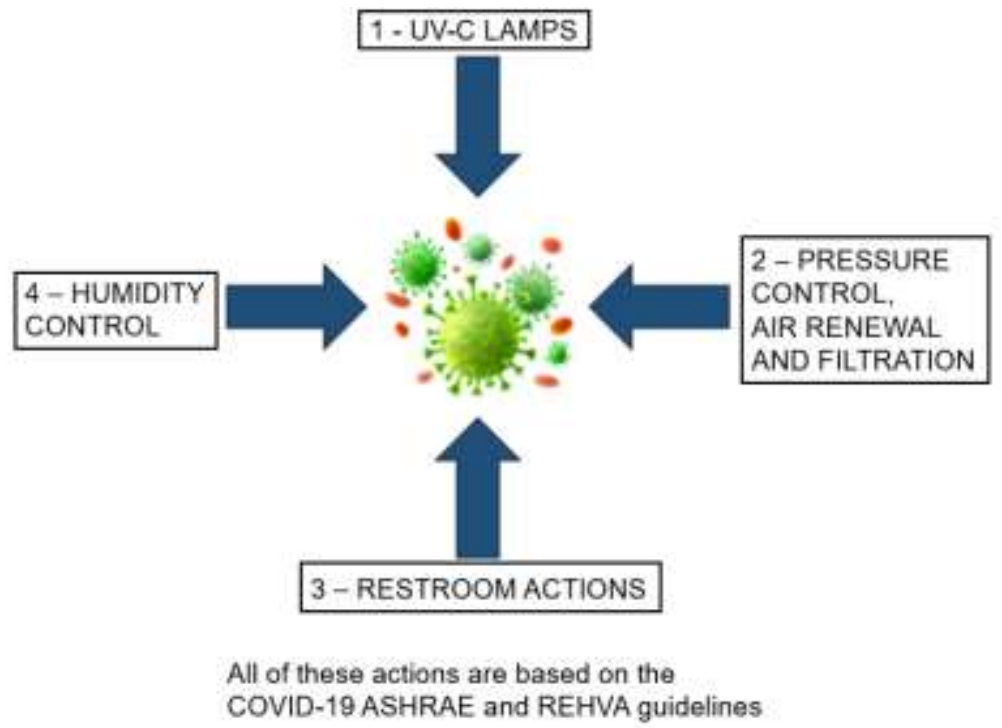

Figure 3. Guidelines applied the UV-C Lamps, Pressure control filtration, Restroom actions and Humidity control to reduce the coronavirus disease (COVID-19) in ICU and hospitals environment, according to ASHRAE and REHVA [17].

\section{First Strategy (room-air cleaners can be useful with ultraviolet germicidal (UV-C) lamps).}

Special ultraviolet (UV) cleaning equipment for supply-air or room-air treatment is effective at killing bacteria and viruses, but the guidance document states this equipment is only suitable for healthcare facilities.

NAFA recommends a properly designed and maintained UV system, often combined with filtration, humidity control, and airflow management, to reduce infections from other viruses. The UV-C light is absorbed by Ribonucleic acid (RNA) and Deoxyribonucleic acid (DNA) in cells and microbes inducing changes (apoptosis) in the DNA/RNA structures that result in their inability to replicate. Many microbes are susceptible to inactivation using UV-C light, including bacteria, viruses, fungi, and spores. The amount of inactivation is directly proportional to the UV-C dose, which is received, and this in turn is the result of its intensity and exposure time $[23,24]$.

UV-C radiation has a short wavelength and high energy, compared to other UV radiation, which enables it to function the best in a direct line and at a short distance. Due to the high energy of the UV-C radiation, it is bound to the inverse square law where the propagation of light intensity decreases exponentially with increasing distance from the light source. Studies developed by Escombe and coauthors [24] and Casanova and coauthors [25] provided that there is a sufficient circulation inside the room to mix the air, upper-room UV fixtures have shown to be an effective asset for use in infection control in high-risk clinical settings.

According to Ryan and coauthors [26], lamps with germicidal ultraviolet irradiation (eUVGI) decreased the proliferation of microbes in HVAC systems. The study was carried out in neonatal intensive care units, and in the ventilation systems of air conditioning units. The result obtained through the research showed that the patients suffered a drop in microbial colonization in the trachea and also had a decrease in the use of antibiotics. The proliferation of multiple bacteria, fungi and microphones were included among the HVAC systems, ICU environment and patients, thus allowing to generate more tests of the results obtained by the application of UV radiation.

In addition to UVC, there are other methods that can be used for that objective, such as the use of Ozone $\left(\mathrm{O}_{3}\right)$ and the Advanced Oxidation processes. The first, stands out for its high oxidative capacity $(2.07 \mathrm{mV})$, making it an excellent sanitizer capable of inactivating several pathogenic microorganisms [27,28,29]. However, both the World Health Organization (WHO) and the Brazilian National Environment Council (Conselho Nacional do Meio Ambiente - CONAMA) regulate the maximum concentrations of this molecule, because when at high levels, it is associated with several respiratory problems [30,31]. As for the Advanced Oxidation processes, also called Active Oxidation, the PHI (Photo Hydro lonization) cells must be highlighted. Its operation occurs through high intensity UV lamps directed and positioned inside the equipment or in the insufflation ducts. This luminous medium when in contact with a specific metallic mesh results in the formation 
of Hydrogen Peroxides $\left(\mathrm{H}_{2} \mathrm{O}_{2}\right)$, hydroxides, superoxide ions and ozone ions in low concentration [32,33]. Thus, these chemical by-products interact with the microorganisms present in the air and on the surface, inactivating them and purifying the environment [34]. Therefore, both processes are efficient in fighting pathogens.

Hospital administrators, governments, and policy makers must work with ICU practitioners to prepare for a substantial increase in critical care room capacity.

\section{Second Strategy (use more window-driven natural ventilation).}

Use more window-driven natural ventilation in buildings without mechanical ventilation. The use of openable windows is recommended, even if this causes thermal discomfort. Even in buildings with mechanical ventilation, open windows can be used to boost ventilation.

Open windows in toilets with passive stack or mechanical exhaust systems may cause contaminated airflow from the toilet to other rooms. So, in these circumstances, it is recommended that toilet windows remain shut. If there is no adequate exhaust ventilation from toilets, and window airflow cannot be avoided, keep windows open in other spaces to achieve cross flows through buildings.

\section{Third Strategy (increase air supply and exhaust ventilation - restroom actions).}

REHVA showed that flushing toilets creates plumes containing droplets, as well as droplet residue when toilets are flushed with open lids. SARS-CoV-2 viruses have been detected in stool samples (reported in recent scientific papers and by the Chinese authorities). Exhaust ventilation systems of toilets should always be kept continuously. Make sure that under pressure is created, especially to avoid the fecal-oral transmission; as shown in Figure.

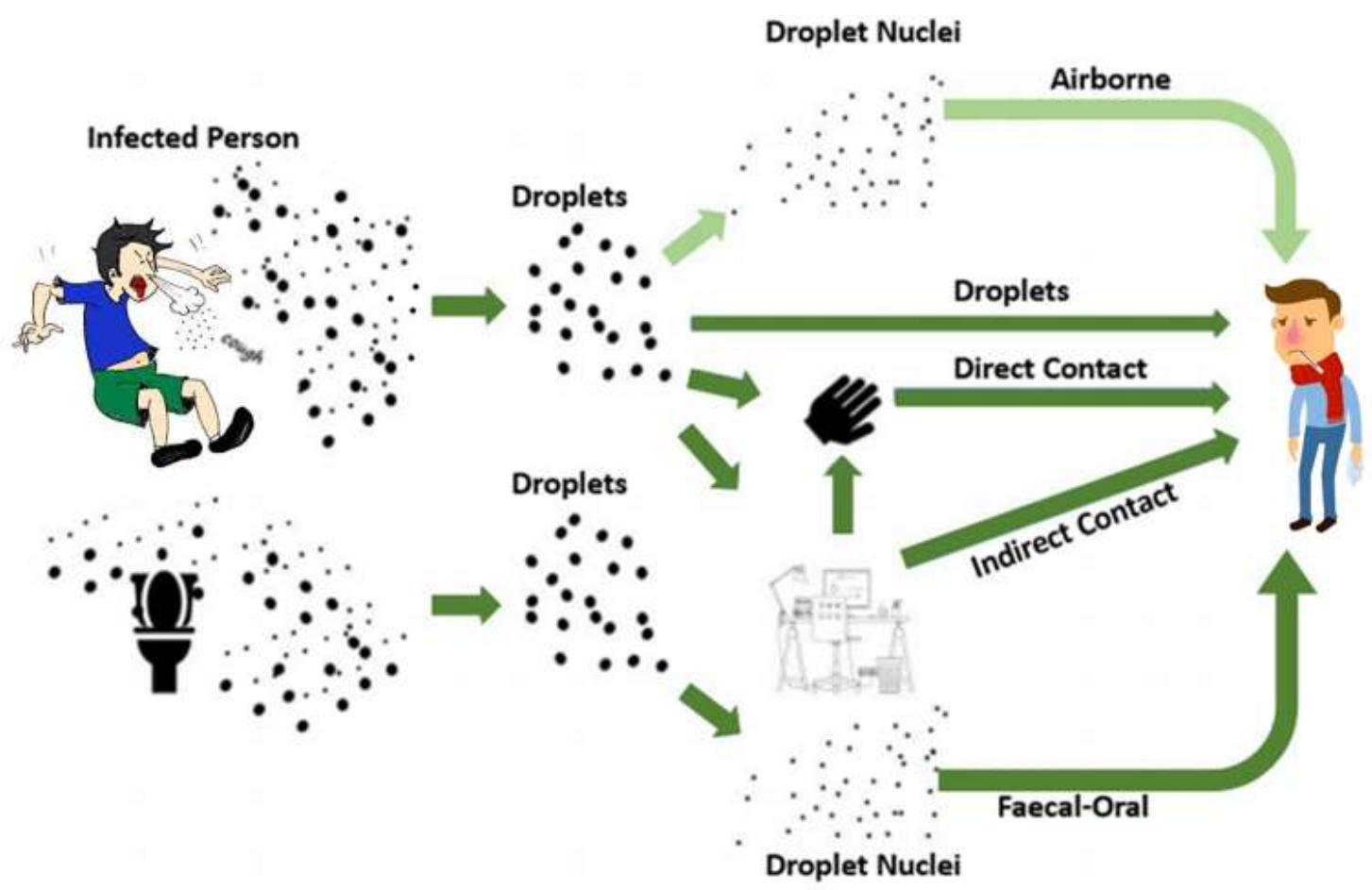

Figure 4. Exposure mechanisms of SARS-CoV-2 droplets (dark green colour). Light green colour: airborne mechanism that is known from SARS-CoV-1 and other flu. Currently there is no evidence specifically for SARS-CoV-2.

Transmission of some viruses in buildings can be limited by changing air temperature and humidity levels. In isolation rooms, the vents are located at the bottom, and airflow is tightly controlled, so air is prevented from "spilling over" into other spaces. It has been found that when it comes to air-conditioned rooms, low values of humidity and temperature can allow respiratory illnesses such as COVID-19 to continue to survive. Such small virus particles stay airborne and can travel long distances carried by airflows in the rooms or in the bathrooms. For example, high-risk immunocompromised patients are often kept within Protective Environment (PE) rooms, designed to limit outside airborne infectious agents from entering into the room. To do this, these rooms are positively pressurized, relative to the corridor space, with a minimum 
of HEPA supply air [18]. However, this pressurization differential also increases the likelihood that aerosols in the patient room will migrate outside of the PE room and into the higher traffic corridor space when the door is open. While PE rooms typically function as intended for the occupant, if an immunocompromised patient is also under treatment for an airborne infectious disease, the process of limiting pathogen ingress into the room could potentially create involuntary exposure to health care workers, other patients, and visitors via the corridor space. In comparison, Airborne Infection Isolation (AII) rooms utilize a negative pressure differential relative to the corridor space and adjacent rooms, directly exhausting room air to the exterior of the building to contain aerosolized pathogens from spreading into circulation and shared spaces. The same negative pressure that aids in preventing spread of aerosolized pathogens from inside the room, can involuntarily expose the room occupants to airborne pathogens that are sourced from occupants of the corridor space. Both PE and All rooms may be designed with an anteroom that is used as an additional buffer between common areas and protected spaces to prevent pathogen spread and provide a location for hospital staff to apply and remove personal protection equipment (PPE). Although contact with contaminated surfaces or people is the biggest source of infection, the aerosol is also a source of contamination where masks may not be sufficient to eliminate contamination. In addition, toilets during flushing can also be a contamination source, therefore, REHVA states that 2 meters away and wearing masks is not enough to protect from infection of Corona Virus SARS-CoV-2. That actions, such as increasing ventilation, is useful to remove additional particles [14].

\section{Fourth Strategy (humidification).}

COVID-19 is resistant to environmental changes and is susceptible only to a very high relative humidity $(\mathrm{RH})$, above $80 \%$, and a temperature above $30^{\circ} \mathrm{C}$, which is not acceptable in terms of thermal comfort.

Humidification is suggested in winter (up to a level of $30 \%$ ) because nasal systems and mucous membranes are more susceptible to infections at very low relative humidity $(\mathrm{RH})$ of $10-20 \%$. However, from March, climatic conditions start to have a $\mathrm{RH}$ higher than $30 \%$ in all European climates, without humidification.

Figure 5 shows that a dry room air $\left(20^{\circ} \mathrm{C}, 20 \% \mathrm{RH}\right)$ and in humid room of $80 \% \mathrm{RH}$, most coronaviruses stay viable for 2 days (blue line; blue star). In room with air of $50 \% \mathrm{RH}$, less than $1 \%$ of viruses are viable after 2 days (red star) [25].

Low temperature increases the persistence of viable viruses on inanimate surfaces (in the study stainless steel, black line), high temperatures decrease the persistence of coronaviruses (yellow line).

At all temperatures ( ${ }^{\circ} \mathrm{C}, 20^{\circ} \mathrm{C}, 40 \stackrel{\circ}{\circ}$ ), the inactivation rate is fastest in intermediate humidity of $50 \%$ $\mathrm{RH}$.

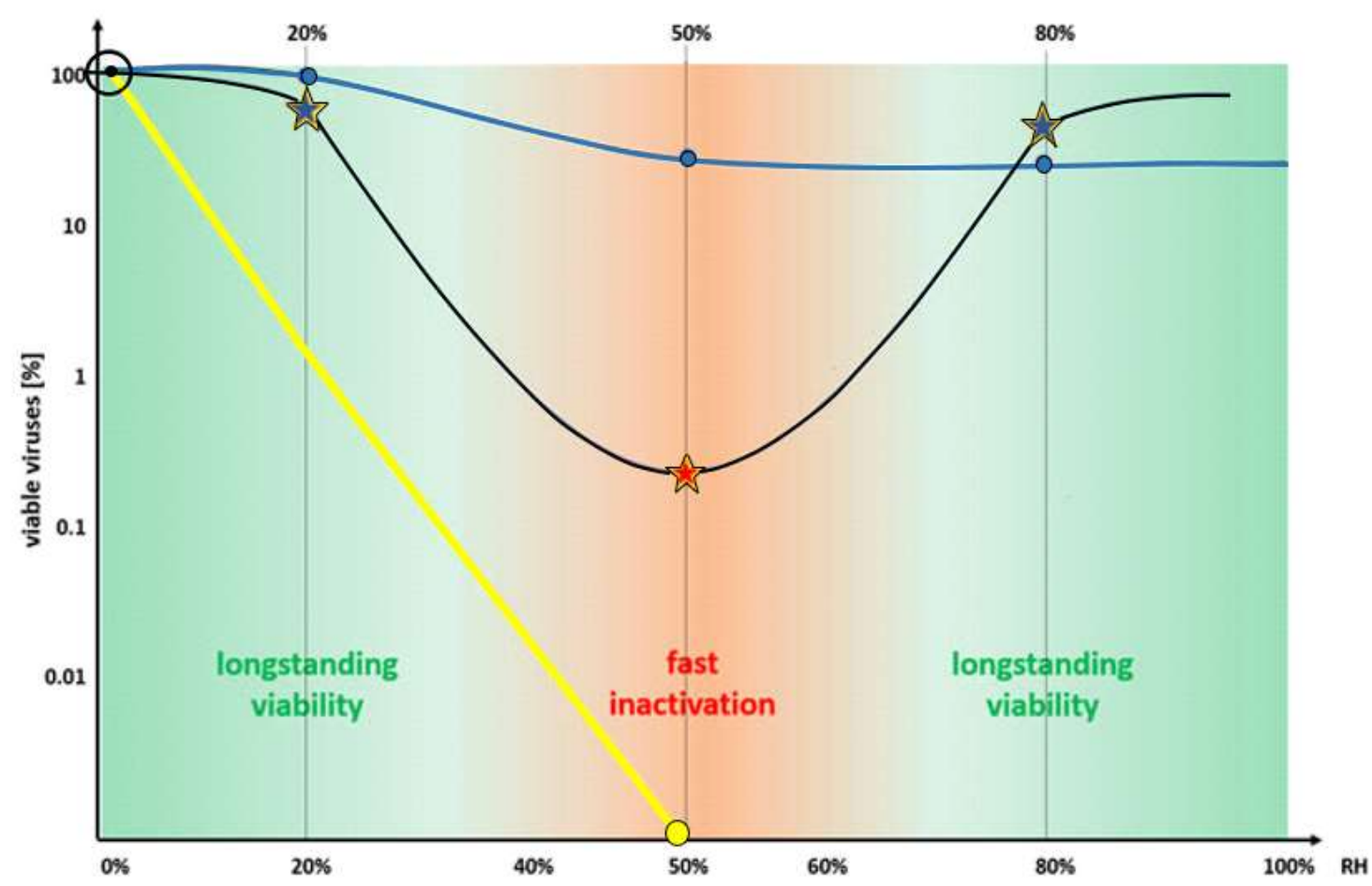

Figure 5. Effects of air temperature and relative humidity on viability of coronavirus on surfaces [25]. 
Taylor and coauthors [35] correlated mid-range humidity levels with improved mammalian immunity against respiratory infections. Mousavi and coauthors [36] reported that $\mathrm{RH}$ values between $40 \%$ and $60 \%$ are most unfavorable climatic conditions for microorganisms' survival. A proper selection, operation, and maintenance of humidification equipment is required when water vapor is introducted in the indoor environment to achieve the mid-range humidity levels associated with decreased infections. Using the SARS study as a basis, the relationship between relative humidity and virus activation is understandable [35, 36].

Casanova and coauthors [25] studied the effects of air temperature and humidity on two surrogates of SARS-CoV, namely transmissible gastroenteritis virus (TGEV) and mouse hepatitis virus (MHV). These viruses could serve as conservative substitutes of SARS-CoV and other coronaviruses for modeling exposure, risk of transmission and control measures for human pathogenic viruses in health care surfaces.

\section{RESULTS AND DISCUSSION}

According to REHVA [14] and ASHRAE guidelines, a schematic shown in Figure 6 was developed to show how aerosols behave and possible solutions to fight it.

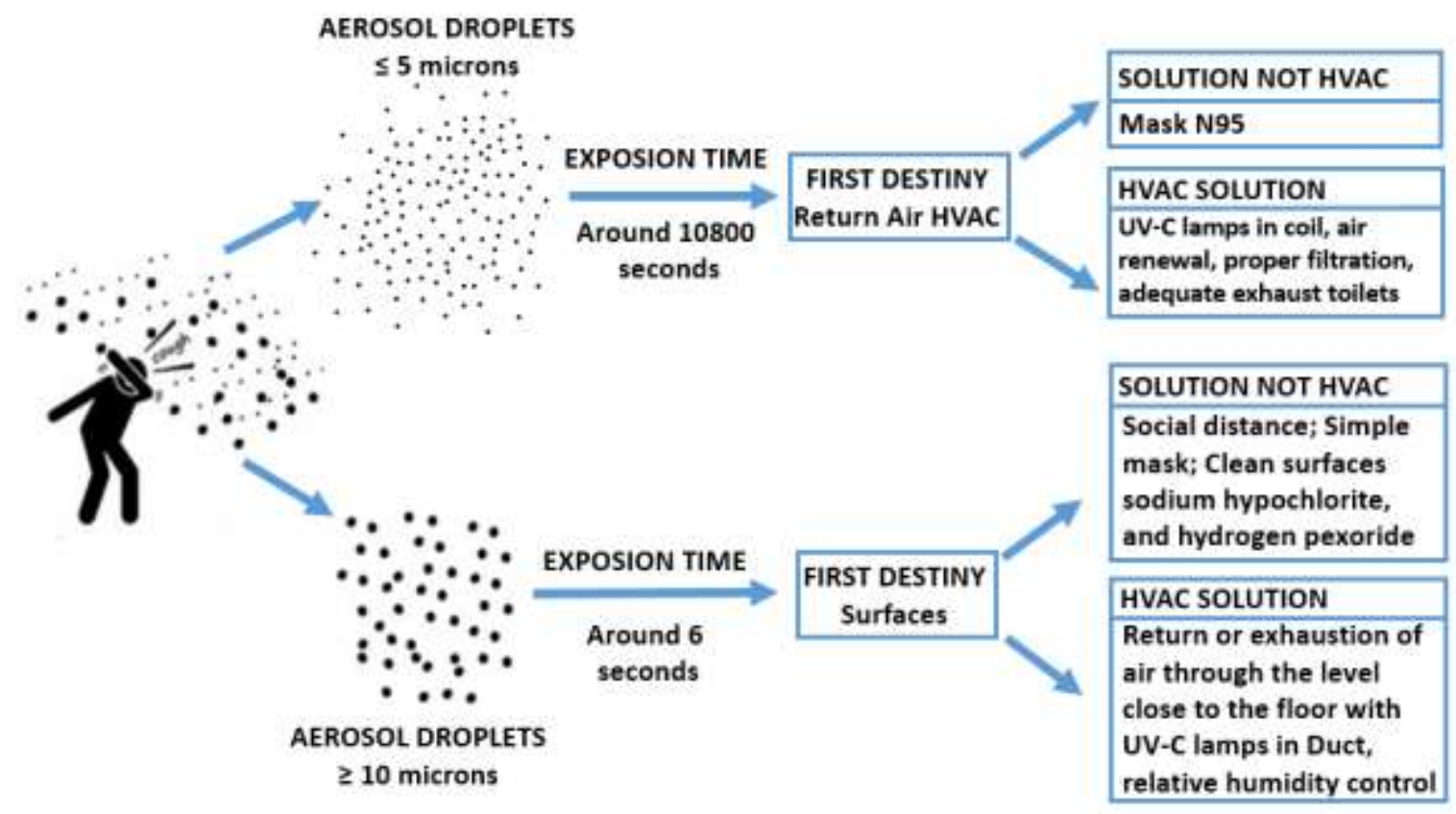

Figure 6. Contagion sources vs strategies to prevent contagion.

The ICU community must be prepared for the challenges associated with this pandemic. Streamlining of workflows for rapid diagnosis and isolation, clinical management, and infection prevention will matter not only to patients with COVID-19, but also to health-care workers and other patients who are at risk from nosocomial transmission [38].

The role of healthcare workers (HCW) in the transmission of pathogens from patient-to-patient is well documented. However, increasing evidence reports the contaminated environment as highly significant in pathogen transmission. A number of factors, including temperature, humidity and severity could influence the concentration of viral particles in an aerosol sample [38].

The Food and Drug Administration of the United States of America (FDA) defines a N95 respirator mask as a respiratory protective device designed to achieve a very close facial fit and very efficient filtration of airborne particles. In addition to blocking splashes, sprays and large droplets, the respirator is also designed to prevent the wearer from breathing in very small particles that may be in the air. While the ultimate effectiveness of these respirator masks is debated, respirator masks are believed to be the best currently available method of protecting against inhalation of highly infectious airborne particles.

Poorly ventilated buildings affect air quality and can contribute to the spread of the disease, as microorganisms, can be transmitted by air-conditioning systems. In health facilities where there is a high concentration of infectious patients, evidence shows that poorly ventilated buildings have higher risks of infectious disease transmission for patients, workers, and visitors. Li and coauthors [38] demonstrated the association between ventilation and air movements in buildings, and the transmission/spread of infectious 
diseases. Although there is insufficient data to specify and quantify the minimum ventilation requirements particularly in hospitals and isolation rooms in relation to spread of infectious diseases via the airborne route, that study supports the use of negatively pressurized isolation rooms in hospitals for patients with these diseases.

We all have a role to play to control the spread of this disease. HVAC is part of it and even more significant are social distancing, hygiene and the influence we can have on personal behavior. Ryan and coauthors [26] showed that the eUVGI decreased HVAC microbial colonization and it was associated with reduced neonatal intensive care unit (NICU) environment and tracheal microbial colonization [20,26].

ASHRAE 55 defines the standards of comfort parameters, the PMV (Predicted Mean Vote) index takes into account the relative humidity, although at a small extend. Thus, the statement that rises from this spreading of viruses, is that air conditioning should no longer be thought for comfort of human, but for comfort for the human, that is, the relative humidity must have a weight as important as the operating temperature. Rethinking a higher air speed even in buildings whose objective is only human comfort, mainly with the return of the air down, can help to change the trajectory of the virus and inject the same in return grids with UV-C lamps [39].

Even Datacenter rooms are already accepting adiabatic systems much of the time, achieving energy savings by the use of indexes like EUED (Energy Usage Effectiveness Design) and TWI (Total Water Impact), where the slightly higher humidity (45\%-65\%) can facilitate the use of an adiabatic system, in addition to allowing higher temperatures for the entry of chilled water into air conditioners, generating better compression ratios and energy savings [40-41].

Furthermore, future designs should reconsider the best way to triage and complete initial assessment of patients that present symptoms related to airborne viruses to minimize exposure to areas with other patient types if possible. In planning for the future, architects, designers, building operators, and health care administrators should aspire for hospital designs that can accommodate periods of enhanced social distancing and minimize connections and flow between common areas, while also affording flexibility for efficient use of space during normal operating conditions.

\section{CONCLUSION}

The role of infection control in the design of hospitals is increasing every day. HVAC systems play an increasingly important role to minimize the risk of infection from airborne transmission within the built environment.

Four strategies were set to change the concept of contaminant air conditioning (due to small droplets passing through the coil, and with the high-speed pressure ventilation being distributed to the occupants) to the concept of an important tool for the inactivation of viruses in the room.

These strategies (see Figure 4): 1) UVC lamps, 2) Pressure control and air renewal/filtration, 3) Restroom actions, 4) Humidity Control to prevent contagion were evaluated in terms of the contagion sources.

In addition, a holistic view of the human comfort was suggested, requiring rethink the PMV index, as humidity has smaller impact on human comfort than on health issue.

\section{REFERENCES}

1. Cowling BJ, Aiello AE. Public health measures to slow community spread of Coronavirus disease 2019. J Infect Dis. 2020;221(11):1749-51. doi:10.1093/infdis/jiaa123.

2. Tan Z, Phoon PHY, Zeng LA, et al. Response and operating room preparation for the COVID-19 outbreak: A perspective from the National Heart Centre in Singapore. J Cardiothorac Vasc Anesth. 2020;S10530770(20)30300-1. doi:10.1053/j.jvca.2020.03.050.

3. Phua J, Weng L, Ling L, et al. Intensive care management of coronavirus disease 2019 (COVID-19): challenges and recommendations [published correction appears in Lancet Respir Med. 2020 May;8(5):e42]. Lancet Respir Med. 2020;8(5):506-17. doi:10.1016/S2213-2600(20)30161-2.

4. Poutanen SM, Low DE, Henry B, et al. Identification of severe acute respiratory syndrome in Canada. N Engl J Med. 2003;348(20):1995-2005. doi:10.1056/NEJMoa030634.

5. Rello J, Tejada S, Userovici C, Arvaniti K, Pugin J, Waterer G. Coronavirus Disease 2019 (COVID-19): A critical care perspective beyond China. Anaesth Crit Care Pain Med. 2020;39(2):167-169. doi:10.1016/j.accpm.2020.03.001. 
6. Gomersall CD, Tai DY, Loo S, et al. Expanding ICU facilities in an epidemic: recommendations based on experience from the SARS epidemic in Hong Kong and Singapore. Intensive Care Med. 2006;32(7):1004-1013. doi:10.1007/s00134-006-0134-5.

7. Lee $\mathrm{N}$, Hui $\mathrm{D}$, Wu A, et al. A major outbreak of severe acute respiratory syndrome in Hong Kong. $\mathrm{N}$ Engl $\mathrm{J}$ Med. 2003;348(20):1986-1994. doi:10.1056/NEJMoa030685.

8. PEBMED. Brasil tem 2 leitos de UTI para cada $10 \mathrm{mil} /$ habitantes. Available at: https://pebmed.com.br/brasil-tem2-leitos-de-UTI-para-cada-10-mil-habitantes/ [Accessed: 2020 May 29th].

9. Noticias.UOL. Um a cada 3 infectados com corona vírus em pé e profissional de saúde. Available at: https://noticias.uol.com.br/saude/ultimas-noticias/redacao/2020/04/14/um-em-cada-3-infectados-com-oronavirusem-pe-e-profissional-de-saude.htm [Accessed: 2020 May 29th].

10. Radonovich LJ Jr, Simberkoff MS, Bessesen MT, et al. N95 respirators vs Medical masks for preventing influenza among health care personnel: a randomized clinical trial. JAMA. 2019;322(9):824-33. doi:10.1001/jama.2019.11645.

11. Public Health Agency of Canada. SARS among Ontario health care workers. SARS Epidemiologic Summaries, 2003. Available at: http:// www.hc-sc.gc.ca/pphb-dgspsp/sars-sras/pef-dep/sarses20030426_e.html. [Accessed: 2020 May 29th].

12. World Health Organization. Hospital infection control guidance for severe acute respiratory syndrome (SARS). Available at: https://www.who.int/ihr/lyon/surveillance/infectioncontrol/en/ [Accessed: 2020 May 29th].

13. Qian $\mathrm{H}$, Zheng $\mathrm{X}$. Ventilation control for airborne transmission of human exhaled bio-aerosols in buildings. J Thorac Dis. 2018;10(Suppl 19):S2295-S2304. doi:10.21037/jtd.2018.01.24.

14. REHVA. REHVA COVID-19 guidance document. Federation of European Heating, Ventilation and Air Conditioning Associations (REHVA). Available at: https://www.rehva.eu/fileadmin/user_upload/REHVA_COVID19_guidance_document_ver2_20200403_1.pdf. [Accessed: 2020 May 29th].

15. Ramaswamy, M, Al-Jahwari, F. Al-Rajhi, S. IAQ in Hospitals - Better Health through Indoor Air Quality Awareness. Proceedings of the 10th International Conference Enhanced Building Operations, Kuwait, October 26-28, 2010.

16. Correia MITD, Ramos RF, Bahten LCV. The surgeons and the COVID-19 pandemic. Os cirurgiões e a pandemia do COVID-19. Rev Col Bras Cir. 2020;47:e20202536. Published 2020 Mar 30. doi:10.1590/0100-6991e-20202536.

17. Schoen, LJ. Guidance for building operations during the COVID-19 pandemic. ASHRAE. Journal May 2020. Available https://www.ashrae.org/file\%20library/technical\%20resources/ashrae\%20journal/2020journaldocuments/7274_ieq_schoen.pdf. [Accessed: 2020 May 29th].

18. ASHRAE. Standard 170 'COVID-19 Guidance' for Hospital Isolation Rooms. . American Society of Heating, Refrigerating and Air-Conditioning Engineers (ASHRAE). 2020. [Accessed: 2020 May 29th].

19. NAFA. COVID-19 (Corona Virus) and Air Filtration Frequently Asked Questions (FAQs). National Air Filtration Association (NAFA). Available at: https://www.nafahq.org/covid-19-corona-virus-and-air-filtration-frequently-askedquestions-

faqs/\#What\%20filter\%20should\%201\%20use\%20to\%20protect\%20those\%20in\%20my\%20building\%20from\%20 COVID-19. [Accessed: 2020 May 29th].

20. Akins, M. Coronavirus and other contaminants: how indoor air quality can affect your health. Air Conditioning Contractors of America Association (ACCA). Available at: https://www.acca.org/news/guest-blog/coronavirusother-contaminants-indoor-air. [Accessed: 2020 May 29th].

21. Elias B, Bar-Yam Y. Could air filtration reduce COVID-19 severity and spread?, New England Complex Systems Institute (March 9, 2020).

22. M. Lindblad, et al., Ultraviolet-C decontamination of a hospital room: Amount of UV light needed. Burns 2019. https://doi.org/10.1016/j.burns.2019.10.004.

23. Casini B, Tuvo B, Cristina ML, et al. Evaluation of an Ultraviolet C (UVC) Light-Emitting Device for Disinfection of High Touch Surfaces in Hospital Critical Areas. Int J Environ Res Public Health. 2019;16(19):3572. Published 2019 Sep 24. doi:10.3390/ijerph16193572.

24. Escombe AR, Moore DA, Gilman $\mathrm{RH}$, et al. Upper-room ultraviolet light and negative air ionization to prevent tuberculosis transmission. PLoS Med. 2009;6(3):e43. doi:10.1371/journal.pmed.1000043.

25. Casanova LM, Jeon S, Rutala WA, Weber DJ, Sobsey MD. Effects of air temperature and relative humidity on coronavirus survival on surfaces. Appl Environ Microbiol. 2010;76(9):2712-2717. doi:10.1128/AEM.02291-09.

26. Ryan RM, Wilding GE, Wynn RJ, Welliver RC, Holm BA, Leach CL. Effect of enhanced ultraviolet germicidal irradiation in the heating ventilation and air conditioning system on ventilator-associated pneumonia in a neonatal intensive care unit. J Perinatol. 2011;31(9):607-14. doi:10.1038/jp.2011.16. 
27. Oliveira, AF, Mendes, HJ. Aplicações clínicas do ozônio na odontologia. Revista Saúde.Com, p. 129-131, 2009. [in Portuguese]

28. Souza, SMO. Estudo da interferência de substratos orgânicos na ação do ozônio sobre microrganismos deteriorantes, benéficos e patogênicos. Available at: https://repositorio.unb.br/bitstream/10482/23292/1/2016_StefaniaMarciadeOliveiraSouza.pdf. [in Portuguese] [Accessed: 2020 May 29th].

29. Medicalnewstoday. What is ozone therapy? Benefits and risks. Available at: https://www.medicalnewstoday.com/articles/320759. [Accessed: 2020 May 29th].

30. WHO. Who challenges world to improve air quality. World Health Organization (WHO). Available at: https://www.who.int/mediacentre/news/releases/2006/pr52/en/. [Accessed: 2020 May 29th].

31. Diário Oficial da União. Resolução, $\mathrm{n}^{0}$ 491, 19 de novembro de 2018. Available at: http://www.siam.mg.gov.br/sla/download.pdf?idNorma=51160. [Accessed: 2020 May 29th]

32. ABRAVA. Tecnologias para descontaminação e combate à infecção em ambientes hospitalares. Revista ABRAVA +Climatização \& Refrigeração, 2020; 71:23. Available at: https://abrava.com.br/wpcontent/uploads/2020/03/revista_abrava_climatiza\%C3\%A7\%C3\%A3o_refrigera\%C3\%A7\%C3\%A3o_fevereiro_ 2020_edi\%C3\%A7\%C3\%A3o_71.pdf. [Accessed: 2020 May 29th]

33. Guardian Air QR +. Available at: https://www.rgf.com/products/air/guardian-air-qr/\#undefined. [Accessed: 2020 May 29th]

34. RGF. Advanced oxidation test results 2000-2019. RFG. Available at: https://www.rgf.com/test-results/. [Accessed: 2020 May 29th]

35. Taylor, S, Tasi, M. 2018. Low indoor-air humidity in an assisted living facility is correlated with increased patient illness and cognitive decline. Proceedings of Indoor Air 2018 744:1-8.

36. Mousavi, E, Lautz, R, Betz, F, Grosskopf. K. Academic Research to Support Facility Guidelines Institute \& ANSI/ASHRAE/ASHE Standard 170. ASHRAE Research Project CO-RP3. Atlanta: ASHRAE, 2019.

37. Weinstein RA. Epidemiology and control of nosocomial infections in adult intensive care units. Am $\mathrm{J}$ Med. 1991;91(3B):179S-184S. doi:10.1016/0002-9343(91)90366-6.

38. Li Y, Leung GM, Tang JW, et al. Role of ventilation in airborne transmission of infectious agents in the built environment-a multidisciplinary systematic review. Indoor Air. 2007;17(1):2-18. doi:10.1111/j.16000668.2006.00445.x

39. ASHRAE. American Society of Heating, Refrigerating and Air-Conditioning Engineers, Inc. 1791 Tullie Circle NE, Atlanta, GA 30329. www.ashrae.org.

40. Santos, AF, de Souza, HJL, Gaspar, PD. 2019. Evaluation of the heat and energy performance of a datacenter for a new efficiency index: Energy Usage Effectiveness Design - EUED. Brazilian Archives of Biology and Technology, 62 (DOI: 10.1590/1678-4324-smart-2019190021).

41. Santos, AF, Gaspar, PD, Souza, HJL. 2020. New index for sustainability - TWI (Total Water Impact). Energies, 13, 1590; doi:10.3390/en13071590.

2020 by the authors. Submitted for possible open access publication under the terms and conditions of the Creative Commons Attribution (CC BY NC) license (https://creativecommons.org/licenses/by-nc/4.0/). 